\title{
Human’s Possession on His Own Life in Islamic and Iranian Doctrine
}

\author{
Hossein Fakhr, Nina H. A. Mohammady \\ University of Tabriz, Tabriz, Iran
}

\begin{abstract}
The aim of this article is to examine religious (Islamic) attitude of human's possession on his own life and its differences with scientific points of view, such as euthanasia permission. According to Islamic doctrine, humans possession on his life is not a pure possession, but a consignment which the God gives to man and the real possessor is the God, so the only role of the man is protecting. On the other hand, according to Iranian criminal code, suicide has not defined as a crime, however, Islamic doctrine does not accept even any harm to men’s own body voluntarily or any kind of suicide attempt. Individualism approach gives the man a strict possession on his life (to continue or cease life). Islamic philosophers (foghaha in Arabic) mentioned reasonable evidences and traditional costumes (naghli evidences) in forbiddance which insist on sanctity of life, and the principal who attempts suicide (if he stays alive) will punish and if he has died, he would be punished by God (oghoobat-e okhravi). After Iran's Islamic revolution in 1979, Iranian criminal system has been completely influenced by the Islamic doctrine in recent three decades. But still, there is not any clear conviction for suicide, so there is a confliction between the two attitudes in criminal law and constitution. Firstly, according to criminal law, (no crime or punishment except in) the act is not crime, unless it is defined as crime in a criminal code. Secondly, according to Iran's constitution (article167) in the silence of law in any especial case, judge would refer to Islamic sources which not only suicidal attempt is defined as a crime, but also there is so much emphasis on convicting the principal. The following points will demonstrate in this article: Does suicide permission relate to democracy and freedom of the Islamic countries nations?; What is suicide conviction in present the Iranians criminal system?; What are the basic reasons of suicide forbiddance in Islam?
\end{abstract}

Keywords: suicide, human rights, self-autonomy, Islamic law

\section{Introduction}

The claim to live and survive is the most eminent equity among the rights of the human being which all the other so-called "human rights" are built upon.

Every true religion's or statute laws back this very essential privilege and sanction any offensive violation through designed to enforce punitive measures.

Therefore, some grievous penalties have been and still are being employed by religions and custom laws to face crimes like murder, battery and alik—no matter voluntarily or involuntarily.

However , even if certain mankind deeds and applications, such as suicide, euthanasia, abortion and so on 
have been highly emphasized on by almost every divine credence unexceptionally, there are still discrepancies being debated among the custom criminal law experts over the issue of whether the above mentioned acts are considered as being crimes and deserving punishments, or not.

The primary reason conflicting custom law and those of the religions, as we believe, is the ethical and heavenly religious view of human's life issue that contradicts the realistic approach by custom law to the same.

This article is briefly examining the Islamic attitude as well as Iranians criminal dealing towards the issue of "suicide".

\section{Inherent Value and the Right of Living in Islam}

According to the Islamic doctrine, human being is the most perfect, noble and valuable cherished of all creature of the God.

And somewhere else in Quran (2008), it says:

And when I have proportioned him and breathed into him of My (created) soul, then fall down to him in prostration. (Chap. Al-hijr, Vs. 29)

And we have certainly honored the children of Adam and carried them on the land and sea and provided for them of the good things and preferred them over much of what we have created, with (definite) preference. (Chap. Al-isra, Vs. 70)

The author of interpretation of the holy Quran, majma-al-bayan, says that, "This verse emphasizes on mankinds' nobelty", and claims that it means, "we gifted the man the superiority in intelligence and conscientiousness to discrete right from wrong along with possession of the good look and lovingly fit figure”(Al-Tarihi in 1395 lunar calendar, Vol. 6, p.152).

Allameh-Tabatabai (n. d.) also in his own interpretation of the same verse assumed that the honoring of man is derived from his power of intelligence and thoughtfulness (Tabatabai, Vol. 13 of Bita, p. 217).

The nobility of man, from Quran's point of view, is so far ahead whom the all mighty in heavens appointed him as his successor on the earth.

(Mention, O Muhammad), when your Lord said to the angels, "Indeed, I will make upon the earth a successive authority". They said, "Will you place upon it one who causes corruption therein and sheds blood, while we declare your praise and sanctify you?". Allah said, "Indeed, I know that which you do not know" (Chap. Al-baqarah, Vs. 30).

Prophet Mohammad, peace be upon him, announces, as well that, “Absolutely, nothing is more dear and valuable in the presence of the God than human being".

Succession of the Lord on earth by man, and man being casted in the God's own mold could also be found in Judaism and Christianity (Old Testament, Book of Genesis, ch.1).

Considering what was said, the doctrine of Islam respects man’s sole and body in full. Quran says killing an innocent is identical to killing the whole mankind and elimination of all signs of life, while saving a single man equates rescution of the entire humanity.

That proves the large number of Qurani verses forbidding murder which a few are mentioned below:

But whoever kills a believer intentionally_-His recompense is Hell, wherein he will abide eternally, and Allah has become angry with him and has cursed him and has prepared for him a great punishment. (Chap. Al-nisa, Vs. 93)

We ordained for them therein a life for a life, an eye for an eye, a nose for a nose, an ear for an ear, a tooth for a tooth, and for wounds is legal retribution. But whoever gives (up his right as) charity, it is an expiation for him. And whoever 
does not judge by what Allah has revealed, then it is those who are the wrongdoers. (Chap. Al-maidah, Vs. 45)

O you who have believed, prescribed for you is legal retribution for those murdered-the free for the free, the slave for the slave, and the female for the female. But whoever overlooks from his brother anything, then there should be a suitable follow-up and payment to him with good conduct. This is an alleviation from your Lord and a mercy. But whoever transgresses after that will have a painful punishment. (Chap. Al-baghare, Vs. 178)

And there is for you in legal retribution (saving of) life, O you (people) of understanding, that you may become righteous. (Chap. Al-baqarah, Vs.179)

Beside the above verses, there are numerous prophetic narration traditions, news and sayings related to Mohammed, his companions, successors, etc., but we restrain ourselves and withdraw further explanations.

\section{Suicide in Islam}

The illegality of unconstitutional act of homicide is precisely defined and accurately stated in Quran and traditions of the Prophet and Shii Imams as general applicable precedent for the victim of murder, injury or battery, and there is not any limitation for it.

Therefore, it includes both homicide, with or without victim's consent and suicide.

And spend in the way of Allah and do not throw (yourselves) with your (own) hands into destruction (by refraining). And do good, indeed, Allah loves the doers of good. (Chap. Al-baqarah, Vs. 195)

The obvious subject of the prohibition in this Verse is suicide. As we all know, the most important reason for committing suicide disappointment, depression, hopelessness and frustration caused by the problem of the life.

This happens where in Moslem's religious literature and in accordance with Prophet Mohammed's statement,

The greatest and the most unforgivable sin in presence of the Mercy killing Lord is the self-deprivation of the vast generousity and the endless mercy fullness of essence of the God.

... do not kill your children out of poverty; We will provide for you and them. And do not approach immoralities-what is apparent of them and what is concealed. And do not kill the soul which Allah has forbidden (to be killed) except by (legal) right. This has he instructed you that you may use reason. (Chap. Al-an’am, Vs. 151)

And repeating elsewhere, it says,

And do not kill your children for fear of poverty. We provide for them and for you. Indeed, their killing is ever a great sin (Chap. Al-isra, Vs. 31) and O you who have believed, do not consume one another's wealth unjustly but only (in lawful) business by mutual consent. And do not kill yourselves (or one another). Indeed, Allah is to you ever Merciful. (Chap. Al-nisa, Vs. 29)

The Prophet also says:

Whoever tries to toll himself using an iron tool, shall reside in hell eternally while hitting himself on his chest with an iron piece. The one who commit suicide by poisoning himself, shall be holding the bowl of poison in his hand and drinking a sip at a tie till he dies and will be staying in the flame of the hell.

And, anybody who jumps of a elevated point to suicide, in fact, has thrown himself in to the hell and is destined to stay there forever. (uode, 1373 solar, p. 176)

All these verses and quotations strongly signal the prohibition of suicide and every kind of physical harm 
in Islam if applied voluntarily. Different prohibitions are due to different looks given at the man by various faiths, and especially the Islamic point of view. The humanitarian look considers the man as the axes of legislation and the law must provide the most of the freedom for the most members of the society and the only limiting point is the point at which one's freedom harms the other's, but in Islam, the God is the sole legislator.

The Islamic belief adjudges the God the absolute authority controlling man's each and every act and attempt in order to notify him of the consequences of his moves. At the same time, the God directs him to the road of salvation.

Basically, in the Islamic attitude, commands are mixed with the ethics, being religion with the faith, and the statute is mixed with the conscience.

So, Muslims obey the rules as a conscience and disobey the rules is regard as a mortal sin.

Sin is not only same act or an omission that is against the social rules and regulation, but also any mistreatment that harms the man himself. (Ardebili, 1379 solar)

Therefore, the human being is the ultimate responsible for his own soul and, but according to the same approach, the human is not considered as the possessor of his very own body. The real owner is the god and man is only holding it as a consignment. Man should maintain this valuable consignment in good shape, use it well and when the time comes, he must deliver it back to the real possessor in good condition.

And do not pursue that of which you have no knowledge. Indeed, the hearing, the sight and the heart-about all those (one) will be questioned. (Chap. Al-isra, Vs. 36)

So, due to the mentioned reasons, suicide, mercy killing, euthanasia and any voluntary physical and mental harms of the body or prohibition ("haram" is the Arabic word for that), then again, some Islamic scholars have banned dangerous and violent sports, such as duel or wrestling.

Some other scholars believe banning some dangerous substances namely cigarette or intoxicating drugs due to the same reasoning.

\section{Suicide in Iranian Statute Law}

Iran is a country, with a majority of Muslim population, which has its law highly influenced by Islamic sources.

After the Islamic revolution in early 1979 and establishing an Islamic Republic regime, it was affected by the Islamic rules and regulation a lot more than before, especially the criminal code which was influenced more than the others.

Based on the Iranian constitution-principle 4, every rule and code in Iran must abide Islamic rules and regulation, or, at least, mustn't be in contrast with them.

And according to the principle 167 of the same constitution, judges are obligated to decide the conviction based on the statute laws. In the absence of a law, they must look it up among Islamic sources: (Quran, precedent of the Prophet and the Imam of shii, consensus of opinions among Muslim jurists and finally the judge's own perception of the case and intellect). No judge is allowed to refuse convicting because of the silence of the law.

These few principles show how influential Islam is over the Iranian laws.

Although Iranian criminal code is influenced by Islamic rules, there is so much emphasis on custom 
criminal law which is commonly used in most criminal system around the world.

However, the principle of "no crime or punishment except in" is accepted in accordance with the Islamic sources, too.

According to principle, 36 of the constitutions state that any punishment verdict should be given by an eligible court.

And according to article 2 of Iran's criminal code, crime is any act or omission which is defined as crime in statute law.

Which is here, the statute law means, "Acts or bills ratified by the Parliament and approved by Guardian council”.

Argument contrary to the principle 36 and article 2 is, "If an act is not defined as crime, it is free to be committed and we cannot accuse anyone of committing it”.

\section{Conclusions}

In this article, we examined human's possession on his own life in accordance with Islamic and Iranian doctrine, in conclusion, according to Islamic doctrine the man who commits suicide would not be punished even though it is prohibited by laws of Islam. That is because death drops down the consequence one's crime.

But if the perpetrator lives, his act shall be regarded as attempted suicide and he will be granted a discretionary punishment (a kind of punishment sentenced by judge).

Although suicide is defined as a crime in Islamic sources, there is not anything said about in Iran's statute law to regard it as a crime or a punishment.

So, in Iranian code, living and surviving is considered a right and not an obligation which means it does not intervene with the personal decision whether to continue or cease one's own life and is close to the Western laws in this essence.

\section{References}

Allameh-Tabatabai. (n. d.). Seied Mohamadhosein, Almizan interpretation (translated by Mohamadbagher Mousavi hamedan, Vol. 13).Tehran, Islamic Publication.

Altarihi, Fakhreddin, Majmaol Bahrein. (1359 Lunar). (Researched by seied ahmad alhoseini, Vol. 6). Tehran, Almaktab almortazavie publication.

Ardebili, Mohammadali. (1373 Solar). General criminal law (Vol. 1, first issue). Mizan publication.

Makarem Shirazi, Naser, et al. (1372 Solar). Nemune interpretation (21th issue). Tehran: Darolkotob aleslamie publication.

Michel, Fishbane. (1988). The image of human and the right of the individual in Jewish tradition. In Levoys, \& Rouner (Eds.), Human rights and the worlds religions. NotreDame, Indiana: University of NotreDame Press.

Mottaghi. (1409 Lunar). Aliebne hesameddin, kanzol amal fi Sonanol ahval va afaal, aljozol sani ashar. Beiroot, moassese alresale publication.

Old Testament. (1973). Book of genesis (ch.1).

Oudat, Abdolghader. (1373 solar). Altashriol jenai aleslami (first issue, translated by Nematollah Olfat, Seied Mahdi Mansoori, Naser Ghorbannia). Abbas Shiri, Mizan publication.

Quran. (2008). Alkarim. Islamieh Publication.

Saiiar, Pirooz. (1380 solar). Books of ancient times (first issue). Tehran, Nei publication. 